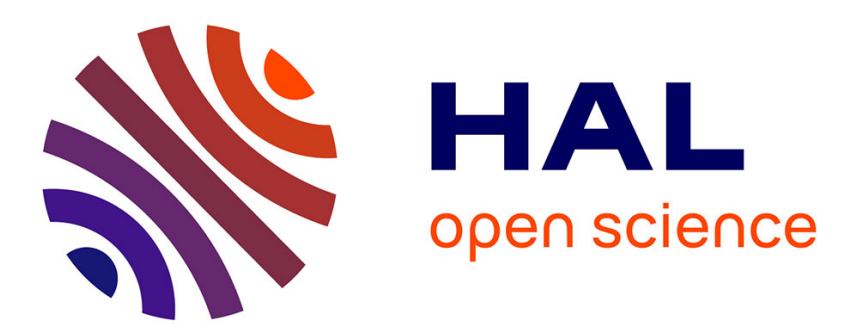

\title{
Two micro-mechanical techniques for studying the enzymatic maceration kinetics of apple parenchyma
}

Jean Francois Maingonnat, Crepin E. Missang, Alain A. Baron, Catherine M.G.C. Renard

\section{- To cite this version:}

Jean Francois Maingonnat, Crepin E. Missang, Alain A. Baron, Catherine M.G.C. Renard. Two micro-mechanical techniques for studying the enzymatic maceration kinetics of apple parenchyma. Journal of Food Engineering, 2014, 122, pp.1-7. 10.1016/j.jfoodeng.2013.08.017 . hal-02631997

\section{HAL Id: hal-02631997 \\ https: / hal.inrae.fr/hal-02631997}

Submitted on 27 May 2020

HAL is a multi-disciplinary open access archive for the deposit and dissemination of scientific research documents, whether they are published or not. The documents may come from teaching and research institutions in France or abroad, or from public or private research centers.
L'archive ouverte pluridisciplinaire HAL, est destinée au dépôt et à la diffusion de documents scientifiques de niveau recherche, publiés ou non, émanant des établissements d'enseignement et de recherche français ou étrangers, des laboratoires publics ou privés. 


\title{
Two micro-mechanical techniques for studying the enzymatic maceration kinetics of apple parenchyma
}

\author{
J.F. Maingonnat ${ }^{\mathrm{a}, \mathrm{b}, *}$, C.E. Missang ${ }^{\mathrm{c}}$, A. Baron ${ }^{\mathrm{d}}$, C.M.G.C. Renard ${ }^{\mathrm{a}, \mathrm{b}}$ \\ a INRA, UMR408 Sécurité et Qualité des Produits d'Origine Végétale, F-84000 Avignon, France \\ ${ }^{\mathrm{b}}$ Université d'Avignon et des Pays de Vaucluse, UMR408 Sécurité et Qualité des Produits d'Origine Végétale, F-84000 Avignon, France \\ ' Unité de Recherche Agrobiologie, Université des Sciences et Techniques de Masuku, BP 941, Masuku Franceville Gabon, Gabon \\ ${ }^{\mathrm{d}}$ INRA, UR 117 Cidricoles et Biotransformation des Fruits et Légumes, F-35000 Rennes, France
}

\begin{abstract}
A B S T R A C T
The enzymatic texture loss during apple maceration was studied by two micro-mechanical techniques. The first technique consisted of a 5\% strain compression cycles at a strain rate of $4.5 \times 10^{-4} \mathrm{~s}^{-1}$. The second technique consisted on micro-puncture of the apple parenchyma with a small needle. The first technique led to the peripheral tissues degradation modelling with a first order kinetic reaction or a more pertinent Weibull function. The second technique evidenced that the jagged part of the load vs penetration curve corresponded to an interaction between the needle tip and the turgescent apple texture and the fractal dimension of this jagged part was chosen as the texture parameter. Modelling the enzyme diffusion phenomenon with the second Fick's law and taking into account the model previously established on peripheral tissues allowed the estimation of an equivalent enzyme diffusivity through the apple parenchyma varying between $3.5 \times 10^{-11}$ and $5.5 \times 10^{-11} \mathrm{~m}^{2} \mathrm{~s}^{-1}$.
\end{abstract}

Keywords:

Micro-mechanics Apple Enzyme degradation Kinetics Diffusion

\section{Introduction}

Apple juice is the second more consumed fruit beverage in Europe (www.aijn.org 2012 Liquid Fruit Market Report) and contains bioactive secondary plant substances such as polyphenols which are responsible of many health benefits (Kujawska et al., 2011). During apple juice processing enzymes are frequently used for enhancing yield and for juice clarification (Ceci and Lozano, 2010). The effect of enzyme types, concentration and operating conditions on the final quality of apple juice has been the subject of much studies, for example Poll (1988), Will et al. (2000, 2002), Mihalev et al. (2004), Sorrivas et al. (2006), Markowski et al. (2009), Jinghua et al. (2011), Oszmianski and Wojdylo (2006), Oszmianski et al. (2009, 2011) and Sandri et al. (2011).

The reaction kinetics was also studied and the main contributions are presented in Table 1 . This table presents the studies performed on apples, pumpkin, potato and carrot which can be considered as fleshy solids. The reaction kinetics was followed by different methods: weighing the liquefied part of the fruit adsorbed on a filter paper (Tanchev et al., 1989, 1990a,b, Tantchev et al., 1993), weighing the non-macerated part of the vegetable (Biekman, 1992; Biekman et al., 1993), final product viscosity loss

* Corresponding author at: INRA, UMR408 Sécurité et Qualité des Produits d'Origine Végétale, F-84000 Avignon, France. Tel.: +33 432722529; fax: +33 432722492.

E-mail address: jean-francois.maingonnat@avignon.inra.fr (J.F. Maingonnat).
(Struebi et al., 1978; Mutlu et al., 1999; Sarığlu et al., 2001), alcohol-insoluble solids in three fractions: residual tissue, single cells (pulp) and juice (Missang et al., 2001a,b), yield and juice viscosity (Sharma et al., 2005); Sun et al., 2006). When a first order kinetic is applied to these results, the reaction constants varied between 0.18 and $86.4 \mathrm{~h}^{-1}$ and the activation energies varied between 30 and $62 \mathrm{~kJ} \mathrm{~mol}^{-1}$.

Although the texture, and particularly the microstructure, of foods plays an important role in the fruit quality (Mebatsion et al., 2008), the nutrients bioavailability (Parada and Aguilera, 2007) or plant-based foods promoting nutritional quality (Van Buggenhout et al., 2012) the microstructure was poorly studied in relation with enzyme maceration. Grazyna et al. (1999) observed by Scanning Electronic Microscopy (SEM) the changes in microstructures of apple tissue treated by four different enzymes and they observed qualitative differences between the enzyme actions on the apple cells. Sorrivas et al. (2006) studied the mechanisms of enzymatic clarification of apple juice by SEM and Transmission Electronic Microscopy (TEM). The role of amylase and pectinase enzymes on the cloudy juice stability was partly explained by these techniques.

The apple tissues were disintegrated by the different enzyme actions leading to a more softened texture. Among the different studies on the fleshy fruits micromechanics, the tensile/compression test and the micro-puncture were pertinent to determine the softening effect of the enzymes. Recent works involving a 
Version définitive du manuscrit publiée dans / Final version of the manuscript published in :

Journal of Food Engineering (2014), Vol. 122, p. 1-7, DOI: 10.1016/j.jfoodeng.2013.08.017

Journal homepage: www.elsevier.com/locate/jfoodeng

Table 1

Kinetics of fruits and vegetables enzymatic maceration as reported in the literature.

\begin{tabular}{|c|c|c|c|c|c|}
\hline Author & Year & Product & Operating conditions & Measurements & $k\left(\mathrm{~h}^{-1}\right) ; E_{a}\left(\mathrm{~kJ} \mathrm{~mol}^{-1}\right)$ \\
\hline Struebi et al. & 1978 & Apple nectars & $\begin{array}{l}1 \text { Commercial enzyme; } 63-1000 \mathrm{mg} / \mathrm{kg} \text {; } \\
0-4 \mathrm{~h}, 38-40^{\circ} \mathrm{C}\end{array}$ & Viscosity loss & $0.24-1.81 \mathrm{~h}^{-1}$ \\
\hline Tantchev et al. & 1989 & $\begin{array}{l}\text { Grated apples and } \\
\text { pumpkins }\end{array}$ & $\begin{array}{l}1 \text { Commercial enzyme; } 200 \mathrm{mg} / \mathrm{kg} ; 0-4 \mathrm{~h} \\
20-40{ }^{\circ} \mathrm{C}\end{array}$ & $\begin{array}{l}\text { Weighing the liquefied part of the } \\
\text { fruit adsorbed on a filter paper }\end{array}$ & $0.21-1.12 \mathrm{~h}^{-1} \approx 62 \mathrm{~kJ} \mathrm{~mol}^{-1}$ \\
\hline Tantchev et al. & 1990 & Grated carrot & $\begin{array}{l}4 \text { Commercial enzymes; } 100 \text { or } 500 \mathrm{mg} / \\
\mathrm{kg} ; 0-6 \text { h } 20-50^{\circ} \mathrm{C}\end{array}$ & $\begin{array}{l}\text { Weighing the liquefied part of the } \\
\text { fruit adsorbed on a filter paper }\end{array}$ & $0.21-0.61 \mathrm{~h}^{-1} \approx 30 \mathrm{~kJ} \mathrm{~mol}^{-1}$ \\
\hline Biekman & 1992 & Potato cubes & $\begin{array}{l}1 \text { Commercial enzyme, } 18.5 \text { and } 15.4 \mathrm{mg} / \\
\text { g; } 0-25 \mathrm{~h} ; 40^{\circ} \mathrm{C}\end{array}$ & $\begin{array}{l}\text { Weighing the non macerated } \\
\text { potato cubes }\end{array}$ & $0.18 \mathrm{~h}^{-1}$ \\
\hline Biekman et al. & 1993 & Potato cubes & $\begin{array}{l}1 \text { Commercial enzyme (cellulase and } \\
\text { hemicellulase activity); } 20-160 \mathrm{mg} / \mathrm{g} \text {; 0- } \\
2 \mathrm{~h} ; 38^{\circ} \mathrm{C} \text {; rotating drum }\end{array}$ & $\begin{array}{l}\text { Weighing the non macerated } \\
\text { potato cubes }\end{array}$ & $0.54-0.75 \mathrm{~h}^{-1 \mathrm{c}}$ \\
\hline Tantchev et al. & 1993 & Apple cubes & $\begin{array}{l}12 \text { Commercial enzymes; } 200- \\
2000 \mathrm{mg} \mathrm{kg}^{-1} ; 0-3.5 \mathrm{~h} ; 20-40^{\circ} \mathrm{C}\end{array}$ & $\begin{array}{l}\text { Weighing the liquefied part of the } \\
\text { fruit adsorbed on a filter paper }\end{array}$ & $0.21-1.81 \mathrm{~h}^{-1} 37.6-83 \mathrm{~kJ} \mathrm{~mol}^{-1}$ \\
\hline Metlu et al. & 1999 & Pectin solutions & $\begin{array}{l}1 \text { Commercial enzyme (pectinase); } 0.05- \\
2.00 \% \mathrm{v} / \mathrm{v} ; 0-0.17 \mathrm{~h}, 15-45^{\circ} \mathrm{C}\end{array}$ & Viscosity loss & $3.6-86.4 \mathrm{~h}^{-1} 38.94 \mathrm{~kJ} \mathrm{~mol}^{-1}$ \\
\hline Missang et al. & $2001 a$ & Apple cubes & $\begin{array}{l}1 \text { Commercial enzyme }\left(\mathrm{PG}^{\mathrm{a}}, \mathrm{PME}^{\mathrm{b}} \text { and }\right. \\
\text { cellulase activities); } 0-26 \mathrm{~h} 25^{\circ} \mathrm{C}\end{array}$ & $\begin{array}{l}\text { Alcohol-insoluble solids in three } \\
\text { fractions: residual tissue, single } \\
\text { cells (pulp) and juice }\end{array}$ & $1.55 \& 0.27 \mathrm{~h}^{-1 \mathrm{~d}}$ \\
\hline Missang et al. & $2001 b$ & Apple cubes & $\begin{array}{l}1 \text { Commercial enzyme } \\
\text { (PG, PME }{ }^{\mathrm{b}} \text { and cellulase activities); 0- } \\
26 \mathrm{~h} 25^{\circ} \mathrm{C} \text {, different apple ripeness }\end{array}$ & $\begin{array}{l}\text { Alcohol-insoluble solids in three } \\
\text { fractions: residual tissue, single } \\
\text { cells (pulp) and juice }\end{array}$ & $2.79-3.94 \mathrm{~h}^{-1} \& 0.39-0.28 \mathrm{~h}^{-1 \mathrm{~d}}$ \\
\hline Sartoglu et al. & 2001 & $\begin{array}{l}\text { Pectin solutions } \\
0.5-3.5 \% \mathrm{w} / \mathrm{v}\end{array}$ & $\begin{array}{l}1 \text { Commercial immobilized enzyme } \\
\text { (pectinase); } 0.1 \mathrm{~g} / \mathrm{ml} \text { particle; } 0-0.33 \mathrm{~h} \text {, } \\
20-90{ }^{\circ} \mathrm{C}\end{array}$ & Viscosity loss & $15.08 \mathrm{~h}^{-1} 50 \mathrm{~kJ} \mathrm{~mol}^{-1}$ \\
\hline Sharma et al. & 2005 & Grated carrot & $\begin{array}{l}\text { Pectolytic and cellulolytic enzymes; } 50- \\
650 \mathrm{mg} / \mathrm{kg} \text {, pect:cellulo ratio } 3: 7-7: 3 \text {, } \\
30-150 \mathrm{~min}, 25-65^{\circ} \mathrm{C}\end{array}$ & Yield, juice viscosity & $2.1 \mathrm{~h}^{-1 \mathrm{c}}$ \\
\hline Sun et al. & 2006 & Carrot pulp & $\begin{array}{l}4 \text { Commercial enzymes; } 0.025-0.1 \mathrm{mg} / \mathrm{g} \text {, } \\
32-88.3 \mathrm{~min} 45^{\circ} \mathrm{C}\end{array}$ & $\begin{array}{l}\text { Yield, juice viscosity, } \beta \text {-carotene } \\
\text { content }\end{array}$ & $2.5 \mathrm{~h}^{-1 \mathrm{c}}$ \\
\hline Diano et al. & 2008 & $\begin{array}{l}\text { Pectin solution } \\
\text { Apple juice }\end{array}$ & $\begin{array}{l}1 \text { Commercial pectolytic enzyme } \\
\text { immobilized on different supports; } 0.3- \\
0.58 \mathrm{mg} / \mathrm{g} ; 0-1.5 \mathrm{~h}, 10-70^{\circ} \mathrm{C}\end{array}$ & Viscosity loss & $4.8-47.4 \mathrm{~h}^{-1}$ \\
\hline
\end{tabular}

\footnotetext{
a Polygalacturonase.

b Pectinmethylesterase.

c Estimation from reported data.

d Two primary mechanisms.
}

miniature tensile device were performed by Oey et al. (2007) and Alamar et al. (2008) to determine respectively the influence of the turgor and the storage conditions on the mechanical behaviour of apple tissues. These works gave very pertinent information at a meso-scale, typically $3 \times 11 \times 5 \mathrm{~mm}^{3}$, on the mechanical resistances of the apple tissues and their evolutions with turgor, storage conditions and cultivars. The tensile stage was placed under a stereomicroscope and the cells deformations were analysed and quantified by image analysis.

The examination of mechanical noise produced during cutting of potato tuber parenchyma tissue and a micro-penetration (probe diameter $20 \mu \mathrm{m}$ ) was applied by Hiller et al. (1996). These micromechanical tests allowed the authors to propose pertinent values of the cell sizes and cell wall stiffness in place without disassembly the parenchyma tissue. A combined acoustic-mechanical profiling was also performed on 86 different apple cultivars by Costa et al. (2011) demonstrating a good performance of their approach in measuring apple crispiness and sensory evaluation.

The aim of the present work was to study the feasibility of two micromechanical tests, a compression and a micro-puncture, to follow the softening of apple tissues when soaking in enzyme solutions.

\section{Materials and methods}

Granny Smith apples were purchased in a local supermarket and stored at $4{ }^{\circ} \mathrm{C}$.

The enzyme used in this work, Endozym ${ }^{\circledR}$ Pectofruit XL (Spindal AEB Group, Gretz-Armanville, France) was extracted from Aspergil- lus niger and was a mix of Polygalacturonases, Pectinesterases and Pectinlysases. The enzyme solutions were prepared with deionized water at $0.5,1.0$ and $2.0 \mathrm{ml} / 100 \mathrm{ml}$ concentrations for the compression tests and the enzyme concentrations were 1.0 and $2.0 \mathrm{ml} / 100 \mathrm{ml}$ for the puncture tests.

The micro-mechanical tests were carried out on a miniature tensile stage DB-T200Petri (Deben Microtest, Suffolk, UK). This equipment is similar to the tensile stage used by Oey et al. (2007) and Alamar et al. (2008) with an additional Petri dish allowing mechanical tests with immersed pieces.

All the experiments are carried on at room temperature about $24^{\circ} \mathrm{C}$.

\subsection{Compression tests}

The apples were longitudinally cut in frites (cross section $7 \times 7 \mathrm{~mm}^{2}$ ) and immersed overnight in a $0.6 \mathrm{M}$ mannitol solution buffered with $\mathrm{K}_{2} \mathrm{HPO}_{4}(0.02 \mathrm{M})$ and $\mathrm{KH}_{2} \mathrm{PO}_{4}(0.02 \mathrm{M})$ to minimise the osmotic pressure effect (Oey et al., 2007). Before performing the compression test, one frite is removed from the beaker and a cubic specimen $\left(7 \times 7 \times 7 \mathrm{~mm}^{3}\right)$ is prepared with parallel blade razor and immersed in a $0.6 \mathrm{M}$ mannitol solution with or without enzyme in the Petri dish of the tensile device (Fig. 1A). The cubic samples were cut in the parenchyma avoiding the skin and the core, the compression is carried on in the radial direction. A preload of $3 \mathrm{~N}$ was applied before the compression phase to ensure a good contact between the apple cube and the grips. The compression test consisted on cycles of compressions; the load was measured with a $100 \mathrm{~N}$ full scale cell. The strain and the speed were respectively $5 \%(0.35 \mathrm{~mm})$ and $0.2 \mathrm{~mm} \mathrm{~min}^{-1}$ corresponding to a 

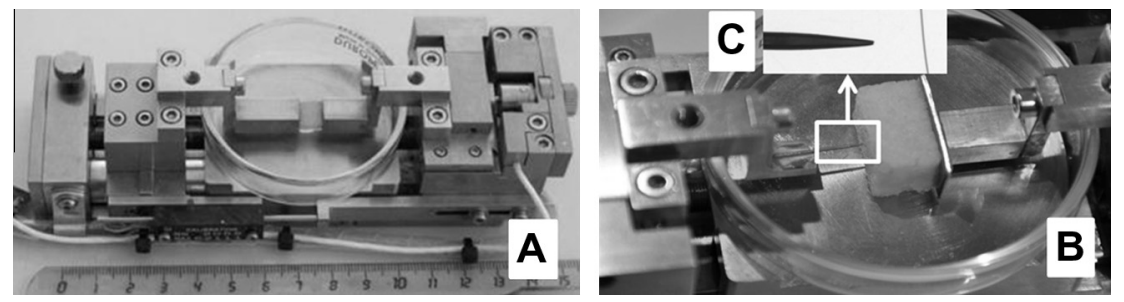

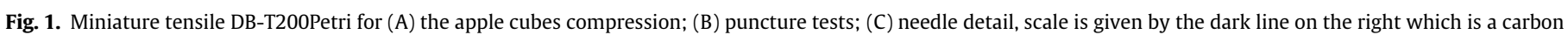
wire (diameter: $30 \mu \mathrm{m}$ ).

strain rate of $4.5 \times 10^{-4} \mathrm{~s}^{-1}$ close to the $5.5 \times 10^{-4} \mathrm{~s}^{-1}$ used by Oey et al. (2007) and Alamar et al. (2008). Preliminary tests (data not shown) indicated that for such a strain the apple mechanical behaviour is almost elastic. Up to 30 cycles are performed without enzyme and when the apple cubes are immersed in enzyme solutions, the experiment was stopped when the measured load vanished. A set of experiments at a specified enzyme concentration consisted on a first compression cycles without enzyme and three or four compression cycles with the enzyme. At each set of experiments a new apple was used for a total of twelve apples.

\subsection{Puncture tests}

One apple was longitudinally cut in frites (cross section $10 \times 10 \mathrm{~mm}^{2}$ ) which were immediately immersed in two $500 \mathrm{ml}$ beakers containing $300 \mathrm{ml}$ of $0.6 \mathrm{M}$ mannitol buffered solutions with and without enzyme. The apple frites represented about $10 \%( \pm 30 \mathrm{~g})$ of the beaker content. The frites are selected avoiding the skin zone and the fruit core. The beaker contents were gently agitated with a magnetic stirrer. Just before the puncture test, one apple frite is removed for the beaker and carefully blotted with paper tissue, except when the apple parenchyma was too 'soft' (long contact times with enzyme). A rectangular apple piece $\left(10 \times 10 \times 20 \mathrm{~mm}^{3}\right)$ was cut with a sharp knife and placed in tensile device Petri dish without any liquid (Fig. 1B). The puncture was carried out with a sewing needle (Fig. 1C) at a speed of $0.5 \mathrm{~mm} \mathrm{~min}^{-1}$, the deflection was $3 \mathrm{~mm}$ for the $2 \mathrm{ml} / 100 \mathrm{ml}$ enzyme concentration and $4 \mathrm{~mm}$ for the $1 \mathrm{ml} / 100 \mathrm{ml}$ enzyme concentration. Three punctures were performed on each apple sample in the radial direction from the external part to the inner part of the apple in the middle of the rectangular apple piece. The load was measured with a $2 \mathrm{~N}$ full scale cell. Visual observations permitted to put the needle tip just in contact with the apple parenchyma before the puncture.

A puncture test was performed in the same operating conditions with a hydrogenated palm oil (Végétaline ${ }^{\circledR}$ ) considered in this study as a quasi-isotropic solid at ambient temperature.

The compression tests allowed the continuous measurement of the peripheral apple tissues enzymatic degradation and the puncture tests allowed the discontinuous measurements of enzymatic degradation of the apple tissues on a 3 or $4 \mathrm{~mm}$ depth.

\subsection{Data analysis}

The compression test data were analysed in terms of load amplitude $(\mathrm{d} L)$ between the maximum strain (5\%) and the initial position at each compression cycle. Taking into account the apple variability, the load amplitude for each compression cycle was divided by the maximum load amplitude $\left(\mathrm{d} L_{\max }\right)$ obtained during the experiment. The enzymatic degradation was firstly considered as a first order reaction.

$\frac{\mathrm{d} L}{\mathrm{~d} L_{\max }}=\exp (-k t)$
In a second step, we considered the cumulative distribution function of the Weibull probability function (Eq. (2)) which is an interesting model for degradation kinetics including a failure to a system after a given time subjected to stress conditions (Cunha et al., 1998; van Boekel, 2009). The parameter $\beta$ ( $h^{-\alpha}$ in this work) is a reaction rate constant and the dimensionless parameter $a$ is a shape factor, $a>1$ indicating a shoulder like curve and an increasing 'failure rate' with time.

$$
\frac{\left(\mathrm{d} L / \mathrm{d} L_{\max }\right)(t)-\left(\mathrm{d} L / \mathrm{d} L_{\max }\right)_{\infty}}{1-\left(\mathrm{d} L / \mathrm{d} L_{\max }\right)_{\infty}}=\exp \left(-\beta t^{a}\right)
$$

The puncture tests data were analysed considering the conical form of the penetration probe in a semi solid material. This type of test was recently applied on a model food material by Özkan et al. (2002) and different mechanical properties are identified from the experiments. For our purpose in this work, the main feature in this test was that the curve load vs displacement is a combination of a 'friction part', leading to a second order shaped curve, and a 'jagged part' due to interactions between the needle tip and the apple micro-texture (Hiller et al., 1996). We neglected the elastic and plastic behaviour of the apple tissue during the penetration test. The first step of data treatment consisted in identifying the best second order modelled curve through the experimental data and in subtracting this modelled curve from the raw data. The second step consisted in removing the background noise of the signal using a mobile mean on the number of points corresponding to a $0.1 \mathrm{~mm}$ displacement; this length corresponding to the mean size of an apple parenchyma cell. This background noise was measured by displacing the jaws without apple cube and this noise depended on the displacement speed (data not shown). Among the numerous methods for studying the jagged part of load vs displacement curves by Roudaut et al. (2002), Yoshioka et al. (2009), Saeleaw and Schleining (2011) we have chosen the box counting method for evaluating the curves fractal dimensions. This method was applied on each displacement of $0.5 \mathrm{~mm}$ on the curve and the obtained numerical values are arbitrarily affected to the middle of the corresponding displacement intervals $(0.25,0.75,1.25,1.75$, etc.). The box counting method was performed with Fractalyse 2.4. free software.

The diffusion in the apple frites was estimated from the classical second Fick's law solution (Ochoa-Martinez et al., 2009) assuming a frite to an infinite plate (Eq. (3)) with $-1<x<+l, D_{\text {eff }}$ the effective diffusivity and $C_{0}$ the enzyme concentration in the surrounding fluid. In the study, $n=6$.

$$
\begin{aligned}
\frac{C(x, t)}{C_{0}}= & 1-\frac{4}{\pi} \sum_{n=0}^{\infty} \frac{(-1)^{n}}{2 n+1} \\
& \times \exp \left\{\frac{D_{e f f}(2 n+1)^{2} \pi^{2} t}{4 l^{2}}\right\} \cos \frac{(2 n+1) \pi x}{2 l}
\end{aligned}
$$




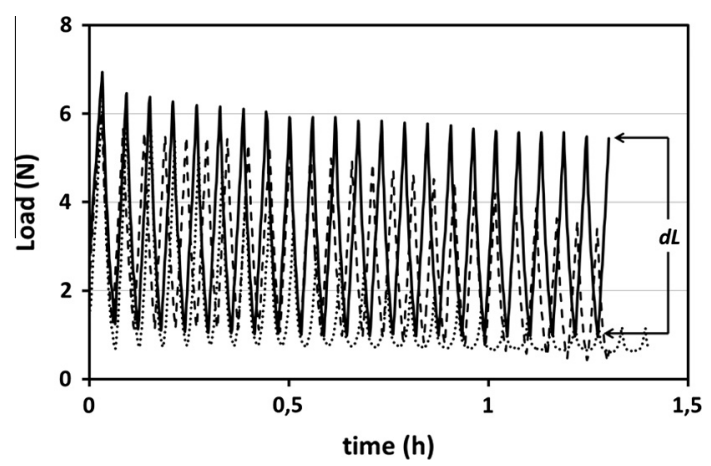

Fig. 2. Representative evolution of the load during a compression cycles test with different enzyme concentration: without enzyme (full line); $0.5 \mathrm{ml} / 100 \mathrm{ml}$ (dashed line); $2.0 \mathrm{ml} / 100 \mathrm{ml}$ (dotted line).

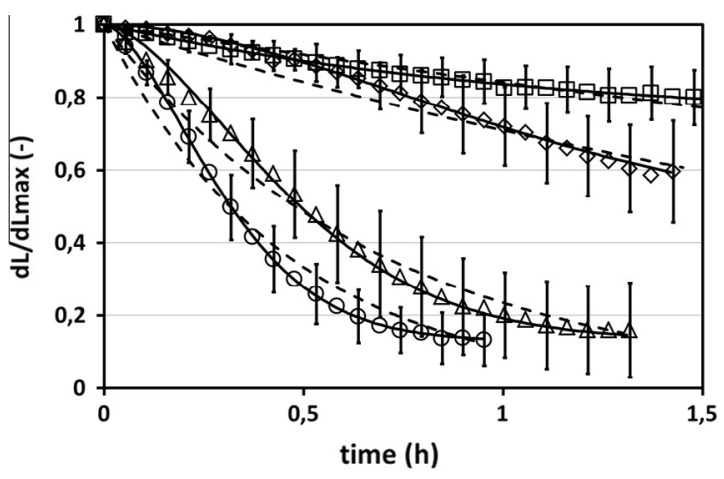

Fig. 3. Kinetics of texture degradation (-) for different enzyme concentrations: $\square$ without enzyme; $\diamond 0.5 \mathrm{ml} / 100 \mathrm{ml} ; \triangle 1.0 \mathrm{ml} / 100 \mathrm{ml} ; \bigcirc 2.0 \mathrm{ml} / 100 \mathrm{ml}$. Dashed lines: first order reaction (Eq. (1)), full lines: Weibull model (Eq. (2)).

\section{Results and discussion}

\subsection{Compression tests}

A representative evolution of the load as a function of time was displayed in Fig. 2 for three enzyme concentrations $(0,0.5$ and $2.0 \mathrm{ml} / 100 \mathrm{ml}$ ). This figures showed that the firsts compression cycles at the beginning of the experiment were almost the same for the different enzyme concentrations; this suggested that, even if the enzyme adsorption on the apple cubes is instantaneous as demonstrated by Missang et al. (2001a), the apple tissues disintegration required few minutes.

The initial compression cycles exhibited a quasi-elastic behaviour of the apple tissues and the corresponding elastic modulus was $2.45 \pm 0.23 \mathrm{MPa}$ which agreed with the results obtained by Oey et al. (2007) and Alamar et al. (2008) at 80\% strain on apples. The elastic modulus values obtained by these authors at small strains were significantly lower (about $0.4 \mathrm{MPa}$ ) perhaps due to an initial compressibility phase of the apple tissues. Oey et al. (2007) and Alamar et al. (2008) evidenced a plastic deformation of the apple tissues when they had unloaded to zero stress, we did not observe such a mechanical behaviour because we had preloaded the apple cubes and never unloaded to zero stress. Apple flesh plastic deformations were evidenced during creep and relaxation experiments by Martinez et al. (2007) and by Salvatori et al. (2011) on raw and treated apples. During these experiments the contribution of the irreversible deformation on the total compliance varied between $7.66 \%$ and $16 \%$ and we decided to neglect this rheological characteristic.

The kinetics of dimensionless amplitude load decreases $(\mathrm{d} L /$ $\mathrm{d} L_{\max }$ ) for different enzyme concentrations and the corresponding modelling results (Eq. (1): dashed lines and Eq. (2): full lines) are presented in Fig. 3 and Table 2.

The reaction rates $k\left(\mathrm{~h}^{-1}\right)$ of the experiments performed without enzyme were significantly different (Table 2) from the experiments with enzyme and we focused our discussion on the enzymatic texture degradation. Fig. 3 indicates that, up to $0.5 \mathrm{~h}$, for low enzyme concentration $(0.5 \mathrm{ml} / 100 \mathrm{ml})$ the texture degradation mechanisms was not clearly different of the experiments without enzyme which could be regarded as an artefact. After that time, the texture degradation was more sensible. For the two other enzyme concentrations, the texture degradation began a few minutes after the immersion in the enzyme solution.

The Weibull modelling (Table 2) indicates that the shape factor $\alpha(-)$ was almost the same for the three enzyme concentrations and the reaction rate $\beta\left(h^{-\alpha}\right)$ increased with enzyme concentrations. The first order reaction rates were $0.343 \mathrm{~h}^{-1}, 1.45 \mathrm{~h}^{-1}$ and $2.20 \mathrm{~h}^{-1}$ respectively for $0.5,1.0$ and $2.0 \mathrm{ml} / 100 \mathrm{ml}$ enzyme concentrations. These reaction rates were in the same order of magnitude than the rates previously observed in the literature (Table 1) and they increased with enzyme concentration. However, we had not been working with enough enzyme concentrations to identify a plateau zone as demonstrated by Missang et al. (2001a).

The concentration dependency of the kinetic constant was linearly modelled as follows:

$K=1.147 C$

\subsection{Puncture tests}

Some representative data obtained during puncture tests of apple cubes immersed or not in enzyme solutions are presented in Fig 4. Fig. 4A represented the raw data (load $v$ s displacement) for a fresh apple cube, an experiment with a solid hydrogenated palm oil and with an apple cube immersed during $16 \mathrm{~h}$ in a $1.0 \mathrm{ml} /$ $100 \mathrm{ml}$ enzyme solution. The following Figs. 4 present the data treatment steps: Fig. 4B load minus 'friction load', Fig 4C mobile mean of the precedent data and Fig 4D the corresponding fractal dimensions.

The results in Fig. 4C and D clearly show that for the fresh apple cube (curve 1) the fractal dimension is almost constant all over the needle displacement and higher than for the solid hydrogenated palm oil (curve 2) indicating a more jagged signal. In the same way, the apple cube immersed during $16 \mathrm{~h}$ in a $1.0 \mathrm{ml} / 100 \mathrm{ml}$ enzyme solution exhibited a low fractal dimension on the 2.5 first millimetres displacement corresponding to a flaccid zone. The last

Table 2

Parameters of compression test modelling with Eqs. (1) and (2).

\begin{tabular}{|c|c|c|c|c|c|c|}
\hline \multirow[t]{2}{*}{ Enzyme $(\mathrm{ml} / 100 \mathrm{ml})$} & \multicolumn{2}{|c|}{ First order reaction } & \multicolumn{4}{|c|}{ Weibull model } \\
\hline & $k\left(\mathrm{~h}^{-1}\right)$ & $r 2$ & $(\mathrm{~d} L / \mathrm{d} L)_{\infty}(-)$ & $\beta\left(h^{-\alpha}\right)$ & $(-)$ & $r 2$ \\
\hline 0 & 0.172 & 0.95 & 0.80 & 0.94 & 1.0 & 0.99 \\
\hline 0.5 & 0.343 & 0.95 & 0.46 & 0.92 & 1.71 & 0.99 \\
\hline 1 & 1.45 & 0.97 & 0.13 & 1.85 & 1.60 & 0.99 \\
\hline 2 & 2.20 & 0.94 & 0.13 & 2.86 & 1.62 & 0.99 \\
\hline
\end{tabular}



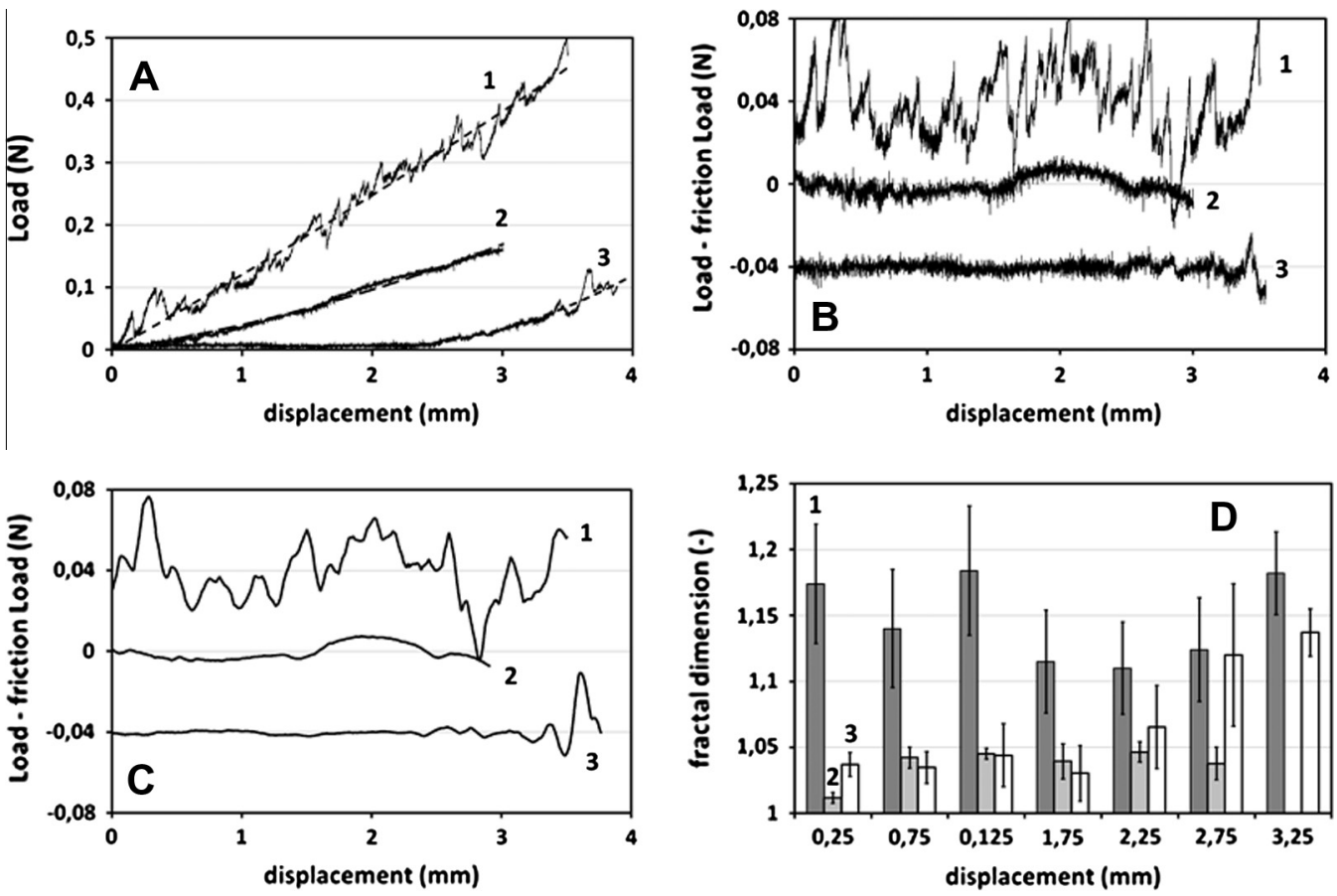





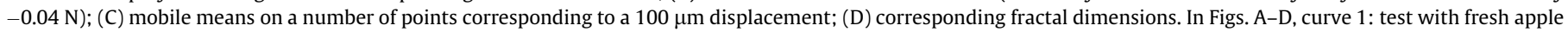

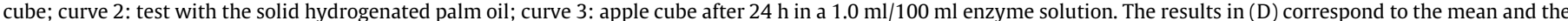

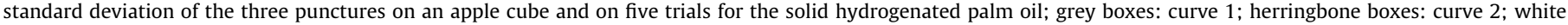
boxes: curve 3 .

displacement millimetre of this curve exhibited a higher fractal dimension. We have also verified that the apple frites immersed during several hours in the mannitol solution without enzyme exhibited the same fractal dimension along the whole displacement than the fresh apple parenchyma (data not shown).

From these experiments we concluded that the jagged part of the puncture curves corresponded to an interaction between the needle tip and the turgescent texture of the apple parenchyma (Yoshioka et al., 2009) and the loss of this texture was due to the enzyme action.

Fig. 5 presents two representative fractal dimension evolutions as a function of the needle displacement and time. In Fig. 5A the apple frites were immersed in a $1.0 \mathrm{ml} / 100 \mathrm{ml}$ enzyme solution up to $24 \mathrm{~h}$. In Fig. 5B the apple frites were immersed in a $2.0 \mathrm{ml} /$ $100 \mathrm{ml}$ enzyme solution up to $6.5 \mathrm{~h}$. The needle displacement was proposed in a dimensionless form $x / l$. The apples inhomogeneity was taken into account by presenting the fractal dimensions $F D$ results in a dimensionless form as follows:

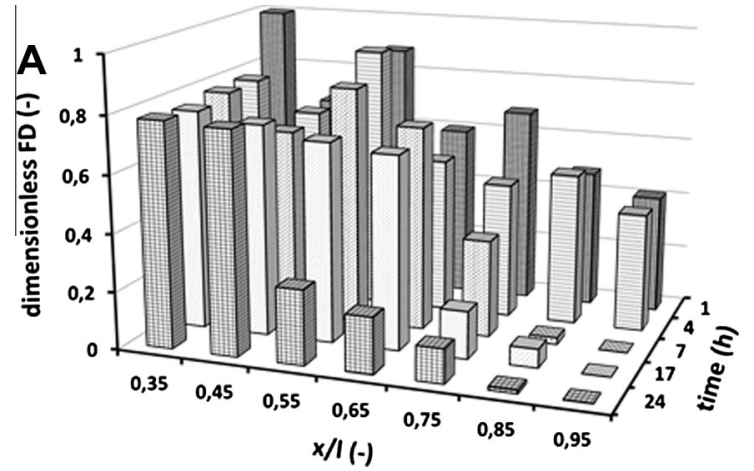

$F D=\frac{F D(x, t)-F D_{\min }}{F D_{\max }-F D_{\min }}$

In the Eq. (5), $F D_{\text {min }}$ and $F D_{\text {man }}$ were respectively the minimum and the maximum fractal dimension values for all the experiments on the concerned apple.

Fig. 5A shows that even after $24 \mathrm{~h}$ the apples frite central part $(x / l<0.45)$ was not affected by the enzymatic activity. On the other hand, the external parts are affected by the enzymatic activity. These remarks and the general curves shapes suggested that a diffusion phenomenon governed the texture loss in the apple pieces.

The two micromechanics approaches combination was performed by using a dimensionless texture parameter $T(x, t)$ which varied between 0 when the fruit was flaccid and 1 when the texture was intact. From the results obtained with the compression tests, we supposed that the texture parameter decrease obeyed exponential decay with time (Eq. (1)) and the kinetics constant was enzyme concentration dependent: $k(C(x, t))$.

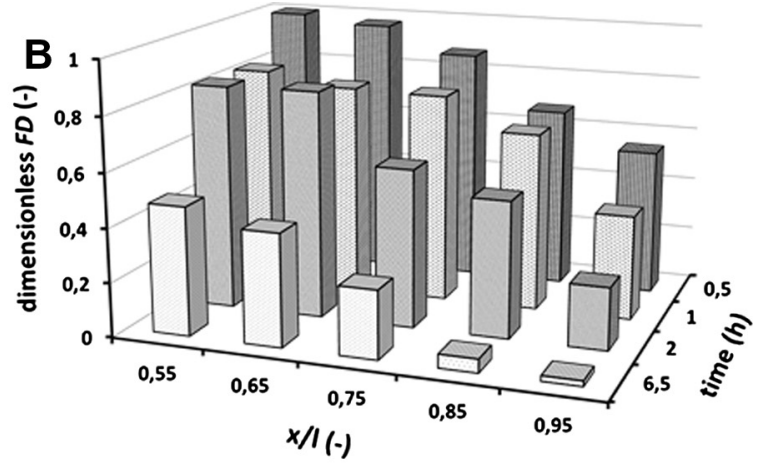

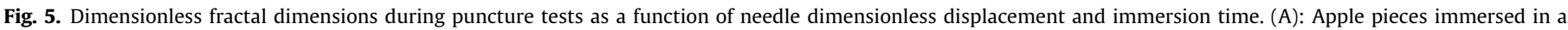
$1.0 \mathrm{ml} / 100 \mathrm{ml}$ enzyme solution up to $24 \mathrm{~h}$. (B): Apple pieces immersed in a $2.0 \mathrm{ml} / 100 \mathrm{ml}$ enzyme solution up to $6.5 \mathrm{~h}$. 

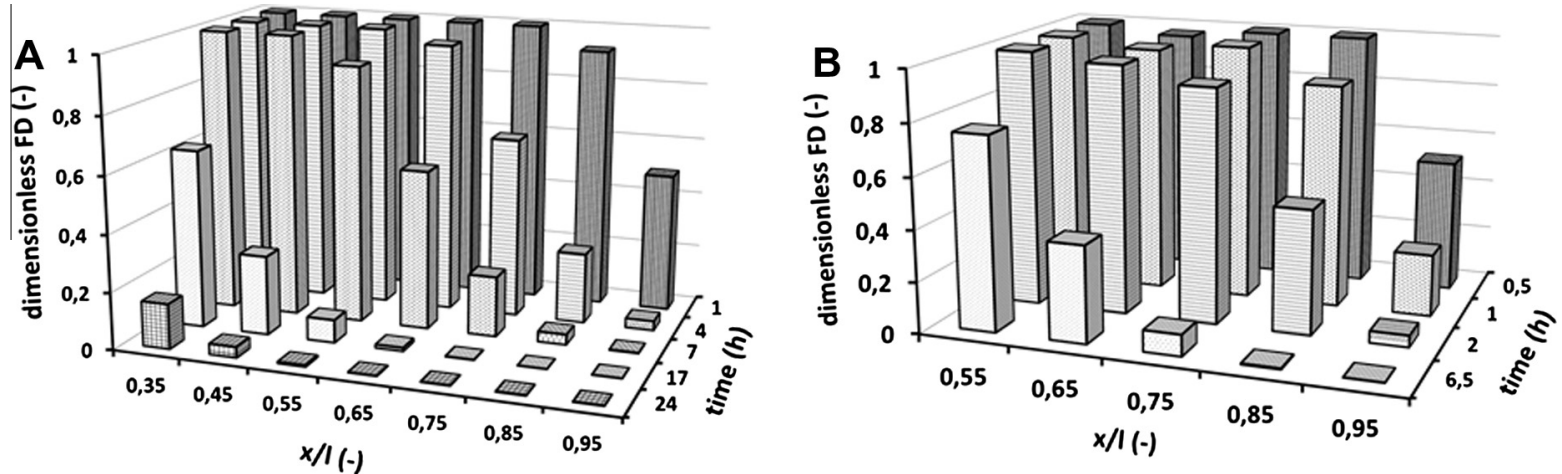

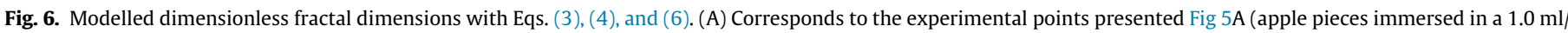

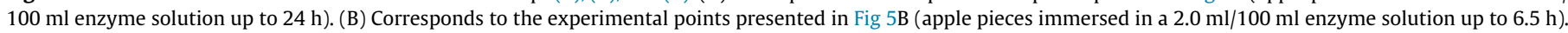

This texture parameter was calculated at a location $(x)$ and a time $(t)$ as follows:

$T(x, t)=\int_{0}^{t} \exp (-k(C(x, t)) t) \mathrm{d} t$

In Eq. (6) $C(x, t)$ is calculated with Eq. (3) and the relation between the kinetics constant and the enzyme concentration was chosen as linear (Eq. (4)). As the fractal dimension in the whole fruit piece was not modified when immersed in a solution of mannitol without enzyme, our last assumption was that below a critical enzyme concentration (arbitrarily fixed at $0.1 \mathrm{ml} / 100 \mathrm{ml}$ ), the fruit texture was not affected. The only adjustable parameter in Eq. (6) was the equivalent diffusivity.

The data concerning the enzyme diffusivity in apple parenchyma are scare. Guillemin et al. (2006) soaked apple cubes in a pectinmethylesterase enzyme and found an enzyme mean dimensionless concentration $C(t) / C_{0}$ equal to $2.15 \times 10^{-2}$ after $1 \mathrm{~h}$ leading to an equivalent diffusivity value close to $1.5 \times 10^{-11} \mathrm{~m}^{2} \mathrm{~s}^{-1}$.

The comparison between experimental and calculated texture parameters are presented in Fig. 6A and B corresponding to the results presented in Fig. 5A and B. The best fittings were obtained for equivalent diffusivities values $3.5 \times 10^{-11} \mathrm{~m}^{2} \mathrm{~s}^{-1}$ for Fig. $6 \mathrm{~A}$ and $5.5 \times 10^{-11} \mathrm{~m}^{2} \mathrm{~s}^{-1}$ for Fig. $6 \mathrm{~B}$. These results agreed with the data obtained by Guillemin et al. (2006).

The comparison between Fig 5A and B showed that the main tendencies were almost the same. The main difference concerned the results obtained at $x / l$ values 0.35 and 0.45 where the experimental data did not evidence any texture loss although the model predicted a texture loss. This difference was probably due to our hypothesis concerning a unique effective diffusivity value for all the experiments. When the fruit texture was severely affected by processes such as osmotic dehydration (Rodrigues and Aparecida Mauro, 2008; Rodriguez and Mauro, 2008; Nahimana et al., 2011), drying (Batista et al., 2007; Ruiz-López et al., 2012) or extracting (Martinez-Vera et al., 2010), the equivalent diffusivity was structure and solute concentration dependent. As far as we know, such studies have not been performed in the case of fruit maceration but we can suppose that the equivalent diffusivity could be lower in flaccid parenchyma. The comparison of Figs. 5B and $6 \mathrm{~B}$ led to the same conclusions for the results obtained after 6.5 h soaking time at $x / l$ value 0.55 .

When modelling the compression tests we had neglected the diffusion phenomenon. Eq. (3) allowed the concentration calculation in the apple cubes and using the above identified effective diffusivity $\left(5 \times 10^{-11} \mathrm{~m}^{2} \mathrm{~s}^{-1}\right)$ the enzyme concentration in the first cell layers, let say $200-400 \mu \mathrm{m}$, is half of external concentration after $1 \mathrm{~h}$. This calculated enzyme concentration validated our assumption.
Further works are required to evidence the texture changes roles in the combined diffusion and texture loss phenomena.

\section{Conclusion}

Two complementary micro-mechanical tests were developed to study the enzyme maceration kinetics of apple parenchyma. The first micro-mechanical test consisted on compression cycles during up to $2 \mathrm{~h}$ and evidenced the enzymatic action kinetics on the peripheral parenchyma tissues. The load amplitude during a compression was considered as a texture parameter and its evolution with maceration time was modelled with a first order reaction and more precisely by a Weibull function. The obtained results agreed with the literature data and a linear relationship between the first order reaction kinetics constant and the enzyme concentration was established. For enzyme concentrations above $1.0 \mathrm{ml} /$ $100 \mathrm{ml}$ the texture loss was completely achieved after $1 \mathrm{~h}$ and half

The second micro-mechanical tests consisted on puncture with a small needle through the apple pieces soaked in enzyme solution up to $24 \mathrm{~h}$. The jagged part of the load vs penetration curve corresponded to an interaction between the needle tip and the turgescent apple texture and we considered the corresponding curve fractal dimension as a dimensionless texture parameter. This texture parameter evolution with time and location suggested that the enzyme diffusion was the limiting factor and the second Fick's law was used as a diffusion mechanism model. When combining the diffusion phenomenon and the previously obtained model for the texture loss in peripheral parenchyma tissues, we identified an enzyme equivalent diffusivity value which in the same order of magnitude than the scare literature data. However the results evidenced that the enzyme diffusivity was greatly influenced by the parenchyma texture and we supposed that the diffusivity decreased when the parenchyma became flaccid or the affinity between enzymes and vegetable tissues may be modified. The same results were observed during fruits air-drying or osmotic dehydration when the parenchyma was shrinking with time leading to a decreased diffusion phenomenon. This work can be transferred to other texture loss operations (thermal, mechanical) and other types of enzyme. Works are also required to visualise the local effects of texture loss operations on the different fruit or vegetable tissues.

\section{Acknowledgments}

The research leading to these results has received funding from the European Community's Seventh Framework Programme (FP7) 2007-2013) under the grant agreement no. FP7-222 654-DREAM. 
The enzyme was provided by Spindal AEB Group, Gretz-Armanville, France.

\section{References}

Alamar, M.C., Vanstreels, E., Oey, M.L., Molto, E., Nicolai, B.M., 2008 Micromechanical behaviour of apple tissue in tensile and compression tests: storage conditions and cultivar effect. Journal of Food Engineering 86 (3), 324 333.

Batista, L.M., Rosa, C.A.da., Pinto, L.A.A., 2007. Diffusive model with variable effective diffusivity considering shrinkage in thin layer drying of chitosan. Journal of Food Engineering 81, 127-132.

Biekman, E.S.A. 1992. Enzymatic maceration of potatoes for the production of instant dried mashed potato - modeling of the disintegration process. Food Biotechnology 6, 19-33.

Biekman, E.S.A., Kroesehoedeman, H.I., Vandijk, C., 1993. Study of the enzymatic maceration kinetics of potatoes in a rotating perforated drum reactor. Food Biotechnology 7, 127-141.

Ceci, LN., Lozano, J., 2010. Use of enzymes for non-citrus fruit juice production. In: Bayindirli, A. (Ed.), Enzymes in Fruit and Vegetable Processing. CRC Press, Taylor \& Francis Group, Boca Raton, USA, pp. 175-195.

Costa, F., Cappellin, L., Longhi, S., Guerra, W., Magnago, P., Porro, D., Soukoulis, C., Salvi, S., Velasco, R., Biasioli, F., Gasperi, F., 2011. Assessment of apple (Malus X domestica Borkh.) fruit texture by a combined acoustic-mechanical profiling strategy. Postharvest Biology and Technology 61, 21-28.

Cunha, L.M., Oliveira, F.A.R., Oliveira, J.C., 1998. Optimal experimental design for estimating the kinetic parameters of processes described by the Weibull probability distribution function. Journal of Food Engineering 37, 175-191.

Granzyna, R.K., Zabernowski, R., Fornal, J., Nesterowicz, J., 1999. The effect of the commercial pectinolytic preparations on the degree of apple tissue desintegration. Fruit Processing 9, 168-172.

Guillemin, A., Degraeve, P., Guillon, F., Lahaye, M., Saurel, R., 2006. Incorporation of pectinmethylesterase in apple tissue either by soaking or by vacuumimpregnation. Microbial Technology 38, 610-616.

Hiller, S., Bruce, D.M., Jeronimidis, G., 1996. Micro-penetration technique for mechanical testing of plant cell walls. Journal of Texture Studies 27 (5), 559587.

Jinghua, Q., Tongyi, C., Yiqing, X., Jun, W., Fang, W., Meixia, P., Manqing, H., 2011. Influence of enzymolysis-adsorption interaction on the secondary haze formation in apple juice. Journal of Food Process Engineering 34, 1793-1803.

Kujawska, M., Ignatowicz, E., Ewertowska, M., Markowski, J., Jodynis-Liebert, J., 2011. Cloudy apple juice protects against chemical-induced oxidative stress in rat. European Journal of Nutrition 50, 53-60.

Markowski, J., Mieszczakowska, M., Plocharski, W., 2009. Effect of apple cultivar and enzyme treatment on phenolic compounds content during clear apple juice production. International Journal of Food Science and Technology 44, 10021010.

Martinez, V.Y., Nieto, A.B., Castrob, M.A., Salvatoria, D., 2007. Viscoelastic characteristics of Granny Smith apple during glucose osmotic dehydration. Journal of Food Engineering 83, 394-403.

Martinez-Vera, C., Ruiz-Martinez, R.S., Vizcarra-Mendoza, M.G., Alvarez-Calderon, J., 2010. Apparent diffusion assessment in extraction process by means of a Luengerger observer. Journal of Food Engineering 101, 16-22.

Mebatsion, H.K., Verboven, P., Ho, Q.T., Verlinden, B.E., Nicolai, B.M., 2008. Modelling fruit (micro)structures, why and how. Trends in Food Science and Technology 19 (2), 59-66.

Mihalev, K., Schieber, A., Mollov, P., Carlet, R., 2004. Effect of mash maceration on the polyphenolic content and visual quality attributes of cloudy apple juice. Journal of Agricultural and Food Chemistry 52, 7306-7310.

Missang, C.E., Baron, A., Drilleau, J.F., 2001a. Enzymatic maceration of apple parenchyma tissue. I. Modelling of the kinetics of hydrolysis. Food Biotechnology 15, 113-133.

Missang, C.E., Baron, A., Drilleau, J.F., 2001b. Enzymatic maceration of apple parenchyma tissue. II. Effect of the degree of ripeness on the kinetic behaviour. Food Biotechnology 15, 135-145.

Mutlu, M., Sarıoğlu, K., Demir, N., Ercan, M.T., Acar, J., 1999. The use of commercial pectinase in fruit juice industry. Part I: Viscosimetric determination of enzyme activity. Journal of Food Engineering 41, 147-150.

Nahimana, H., Zhang, Min, Mujumdar, A.S., Ding, Zhangshen, 2011. Mass transfer modeling and shrinkage consideration during osmotic dehydration of fruits and vegetables. Food Reviews International 27, 331-356.

Ochoa-Martinez, C.I., Ramaswamy, H.S., Ayala-Aponte, A.A., 2009. Suitability of Crank's solutions to Fick's second law for water diffusivity calculation and moisture loss prediction in osmotic dehydration of fruits. Journal of Food Process Engineering 32, 933-943.

Oey, M.L., Vanstreels, E., De Baerdemaeker, J., Tijskens, E.H., Ramon, H., Hertog, M.L.A.T.M., Nicolai, B., 2007. Effect of turgor on micromechanical and structural properties of apple tissue: a quantitative analysis. Postharvest Biology and Technology 44, 240-247.

Oszmianski, J., Wojdylo, A., 2006. Effect of pectolytic enzyme preparations on the phenolic composition and antioxidant activity of apple juice. Fruit Processing $16,322-329$.
Oszmianski, J., Wojdylo, A., Kolniak, J., 2009. Effect of enzymatic mash treatment and storage on phenolic composition, antioxidant activity, and turbidity of cloudy apple juice. Journal of Agricultural and Food Chemistry 57, 7078-7085. Oszmianski, J., Wojdylo, A., Kolniak, J., 2011. Effect of pectinase treatment on extraction of antioxidant phenols from pomace, for the production of pureeenriched cloudy apple juices. Food Chemistry 127, 623-631.

Özkan, N., Xin, H., Chen, H.D., 2002. Application of a depth sensing indentation hardness test to evaluate the mechanical properties of food materials. Food of Food Science 67 (5), 1814-1820.

Parada, J., Aguilera, J.M., 2007. Food microstructure affects the bioavailability of several nutrients. Journal of Food Science 72 (2), R21-R32.

Poll, L., 1988. The effect of pulp holding time on volatile components in apple juice (with and without pectolytic treatment. Lebensmittel-Wissenschaft \& Technologie 21, 87-91.

Rodrigues, A.E., Aparecida Mauro, M., 2008. Effective diffusion coefficients behavior in osmotic dehydration of apple slices considering shrinking and local concentration dependence. Journal of Food Process Engineering 31, 207-228.

Rodriguez, A.E., Mauro, M.A., 2008. Effective diffusion coefficients behavior in osmotic dehydration of apple slices considering shirking and local concentration dependence. Journal of Food Process Engineering 31, 207-228.

Roudaut, G., Dacremont, C., Pàmies, Vallès, Colas, B., LeMeste, M., 2002. Crispness, a critical review on sensory and material science approaches. Trends in Food Science and Technology 13, 217-227.

Ruiz-López, I.I., Ruiz-Espinosa, H., Arellanes-Lozada, P., Bárcenas-Pozos, M.E., García-Alvarado, M.A., 2012. Analytical model for variable moisture diffusivity estimation and drying simulation of shrinkable food products. Journal of Food Engineering 108, 427-435.

Saeleaw, M., Schleining, G., 2011. A review: crispness in dry food and quality measurements based on acoustic-mechanical destructive techniques. Journal of Food Engineering 105, 387-399.

Salvatori, D., Doctorovitch, R.S., Alzamora, S.M., 2011. Impact of calcium on viscoelastic properties of fortified apple tissue. Journal of Food Process Engineering 34, 1639-1660.

Sandri, I.G., Fontana, R.C., Barfknecht, D.M., Silveira, M.M.d., 2011. Clarification of fruit juices by fungal pectinases. LWT - Food Science and Technology 44, 22172222 .

Sarıoğlu, K., Demir, N., Acar, J., Mutlu, M., 2001. The use of commercial pectinase in the fruit juice industry, Part 2: Determination of the kinetic behaviour of immobilized commercial pectinase. Journal of Food Engineering 47, 271-274.

Sharma, A.K., Sarkar, B.C., Sharma, H.K., 2005. Optimization of enzymatic process parameters for increased juice yield from carrot (Daucus carota L.) using response surface methodology. European Food Research and Technology 221, $106-112$.

Sorrivas, V., Genovese, D.B., Lozano, J.E., 2006. Effect of pectinolytic and amylolytic enzymes on apple juice turbidity. Journal of Food Processing and Preservation 30, 118-133.

Struebi, P., Escher, F.E., Neukom, H., 1978. Use of macerating pectic enzymze in apple nectar processing. Journal of Food Science 43, 260-263.

Sun, Y., Wang, Z., Wu, J., Chen, F., Liao, X., Hu, X., 2006. Optimising enzymatic maceration in pretreatment of carrot juice concentrate by response surface methodology. International Journal of Food Science and Technology 41, 1082 1089.

Tanchev, S., Mälkki, Y., Tancheva, E.S., Videv, K., 1989. Kinetics of apple and pumpkins maceration with Pectinex 3 x L. In: Spiess, W.E.L., Schubert, H. (Eds.), Engineering and Food, Advanced Process. Elsevier Applied Science, London and New York, pp. 625-636.

Tanchev, S., Tancheva, E.S., Raev, N., 1990. Kinetic of the enzymatic maceration of carrot. Confructa Studien V/VI-6-90, 160-162.

Tantchev, S., Malkki, Y., Pessa, E., Kinnunen, A., Mokkila, M., 1990. An absorption weighing method for determining the degree of enzymatic maceration in fruit and vegetables. Acta Alimentaria 19, 261-271.

Tantchev, S., Maelki, Y., Raev, N., Vainionpaeae, J., Kostov, A., 1993. Kinetics of the enzymatic maceration of apples. Fluessiges Obst 60, 259-261.

van Boekel, AJS., 2009. Chemical reactions kinetics. In: van Boekel, A.J.S. (Ed.), Kinetics Modeling of Reactions in Foods. CRC Press, Taylor \& Francis Group, Boca Raton, USA (pp. 4-26).

Van Buggenhout, S., Ahrné, L., Alminger, M., Andrys, A., Benjamin, M., Bialek, L., Cleaver, G., Colle, I., Langton, M., Larqué, E., Lemmens, L., Löfgren, A., LopezSanchez, P., Pérez-Llamas, F., Martínez-Tomás, R., Robertson, J., Schalow, S., Svelander, C., Wellner, N., Hendrickx, M., Waldron, K., 2012. Structural design of natural plant-based foods to promote nutritional quality. Trends in Food Science and Technology 24, 47-59.

Will, F., Bauckhage, K., Dietrich, H., 2000. Apple pomace liquefaction with pectinases and cellulases: analytical data of the corresponding juices. European Food Research and Technology 211, 291-297.

Will, F., Schulz, K., Ludwig, M., Otto, K., Dietrich, H., 2002. The influence of enzymatic treatment of mash on the analytical composition of apple juice. International Journal of Food Science and Technology 37, 653660.

Yoshioka, Y., Horie, H., Sugiyama, M., Sakata, Y., 2009. Quantifying cucumber fruit crispness by mechanical measurements. Breeding Science 59, 139147. 